\title{
Incorporating a continuous suction system as a
} preventive measure against fistula-related complications
in head and neck reconstructive surgery

\author{
Hsien Pin Chang ${ }^{1}$, Jong Won Hong ${ }^{1}$, Won Jai Lee ${ }^{1}$, Young Seok Kim², Yoon Woo Koh ${ }^{3}$, \\ Se-Heon Kim ${ }^{3}$, Dae Hyun Lew ${ }^{1}$, Tae Suk Roh ${ }^{2}$ \\ ${ }^{I}$ Department of Plastic and Reconstructive Surgery, Institute for Human Tissue Restoration, Severance Hospital, Yonsei University College of \\ Medicine, Seoul; ${ }^{2}$ Department of Plastic and Reconstructive Surgery, Institute for Human Tissue Restoration, Gangnam Severance Hospital, \\ Yonsei University College of Medicine, Seoul; ${ }^{3}$ Department of Otorhinolaryngology, Institute for Human Tissue Restoration, Severance \\ Hospital, Yonsei University College of Medicine, Seoul, Korea
}

Background Although previous studies have focused on determining prognostic and causative variables associated with fistula-related complications after head and neck reconstructive surgery, only a few studies have addressed preventive measures. Noting that pooled saliva complicates wound healing and precipitates fistula-related complications, we devised a continuous suction system to remove saliva during early postoperative recovery.

Methods A continuous suction system was implemented in 20 patients after head and neck reconstructive surgery between January 2012 and October 2017. This group was compared to a control group of 16 patients at the same institution. The system was placed orally when the lesion was on the anterior side of the retromolar trigone area, and when glossectomy or resection of the mouth floor was performed. When the orohypopharynx and/or larynx were eradicated, the irrigation system was placed in the pharyngeal area.

Results The mean follow-up period was $9.2 \pm 2.4$ months. The Hemovac system was applied for an average of 7.5 days. On average, 6.5 days were needed for the net drain output to fall below $10 \mathrm{~mL}$. Complications were analyzed according to their causes and rates. A fistula occurred in two cases in the suction group. Compared to the control group, a significant difference was noted in the surgical site infection rate $(P<0.031)$.

Conclusions Clinical observations showed reduced saliva pooling and a reduction in the infection rate. This resulted in improved wound healing through the application of a continuous suction system.

Keywords Saliva / Fistula / Suction / Infection
Correspondence: Jong Won Hong Department of Plastic and Reconstructive Surgery, Yonsei University College of Medicine, 50 Yonsei-ro, Seodaemun-gu, Seoul 03722 , Korea

Tel: +82-2-2228-2215

Fax: +82-2-393-6947

E-mail: hsaturn@hanmail.net

This article was presented at the Research \& Reconstructive meeting on April 20, 2017, in Seoul, Korea.

We would like to thank Mr. Dong-su Jang for his illustrations.

\section{INTRODUCTION}

With advancements in microsurgery and medicine, many cen- ters perform reconstructive surgery after the eradication of head and neck cancers [1-3]. A consensus has nearly been reached on the surgical method and the types of flaps and vessels that 
should be utilized for head and neck reconstruction, and the success rates of these procedures have been increasing. However, despite improvements in microsurgical methods and techniques, the rates of fistula formation have not meaningfully improved [4-9]. Fistula formation after head and neck reconstruction begins with wound healing complications, and fistulas ultimately lead to increased morbidity and mortality $[2,4,7,8,10]$. Although not every patient with a fistula experiences a longer hospital stay or a delay in subsequent medical treatment, it is necessary to address this issue due to the poor quality of life and overall discomfort that patients may endure after head and neck reconstruction.

Thus far, studies have addressed the causes and risk factors of fistula formation. In addition, flap choices and suture methods have been evaluated [1-3,7,10-14]. In most of the studies, large numbers of patients were evaluated to identify statistical correlations between various prognostic and causative factors and fistula formation. Previous studies have shown primary tumor stage, preoperative radiotherapy status, duration of surgery, and delayed wound healing to be risk factors of fistula formation $[1,3,9,15,16]$. However, only a few studies have addressed the methods used to reduce risk factors associated with fistula formation, such as delayed wound healing.

Another well-studied risk factor predisposing patients to fistula formation is surgical site infection. In a recent series of 504 free flaps, methicillin-resistant Staphylococcus aureus (MRSA) was shown to be associated with a higher likelihood of postoperative fistula formation [17]. Poor oral hygiene is also a significant contributor to the development of wound complications [18].

We observed that a pool of saliva forms in the oral and hypopharyngeal areas as a result of postoperative edema, tongue retrusion, and hypopharyngeal collapse. This pooled saliva may precipitate fistula formation in patients with poor oral hygiene and exacerbate surgical site infection, causing the wound healing process to deteriorate further. Moreover, salivary leakage through the fistula tract during the postoperative period exposes the carotid to the enzymatic action of saliva and increases the risk of devastating carotid blowout [19].

Therefore, we hypothesized that elimination of this saliva pool would help maintain oral hygiene and reduce the risk factors associated with fistula formation, such as delayed wound healing.

To eliminate pooled saliva, a continuous suction system with a Hemovac tube was devised and placed in the oral and/or nasohypopharyngeal area of patients who underwent head and neck reconstruction. This patient group was compared to a control group who underwent reconstruction after head and neck surgery without placement of the system. By comparing the clinical outcomes between these two groups, we aimed to evaluate the efficacy of this system.

\section{METHODS}

\section{Patients}

The study was approved by the Institutional Review Board (IRB No. 4-2018-0402). In this retrospective study, we reviewed the medical records of 20 patients in whom the Hemovac irrigation system was placed after head and neck reconstructive surgery between January 2012 and October 2017. The medical records of these patients were compared to those of 16 patients who underwent surgery in the same period without the irrigation system. The types of flaps used were restricted to the anterolateral thigh flap, rectus musculocutaneous flap, and fibular osteocutaneous flap. All reconstructive operations were performed at a single institution. Both groups received routine general care after surgery, including tracheostomy, L-tube insertion, medical treatment, and other conservative measures.

\section{Continuous suction system setting}

Since the saliva pools were in the oral or pharyngeal areas, the system was divided into an oral setting and pharyngeal setting. The selection of which setting to apply was based on whether pharyngeal reconstruction was performed. The irrigation system was placed orally when the reconstructed lesion was on the anterior of the retromolar trigone area, and in cases in which glossectomy or resection of the mouth floor was performed. When the orohypopharynx and/or larynx were eradicated, the irrigation system was placed in the pharyngeal area.

We used a Hemovac tube, as it is routinely used and easy to obtain. We used a soft silicone Hemovac tube with a $4.8-\mathrm{mm}$ outer diameter and a 2.8-mm inner diameter (Barovac 400, PS type; Sewoon Medical, Seoul, Korea). The tube was set in a Ushape configuration when placed in the oral setting. For pharyngeal suction, the tube was placed in the hypopharynx via the nose, similar to the procedure for L-tube insertion. The tube was placed $2 \mathrm{~cm}$ away from the margin of the flap to avoid irritating the sutured flap margin. The eyelets of the Hemovac tube were stationed within the nostril or oral cavity (Fig. 1), since suction is ineffective when eyelet holes are exposed. The tube was anchored on gingival mucosa between the first premolar and canine teeth after the tube was placed in a U-shaped manner by using Vicryl 3-0 sutures (Fig. 2). In the pharyngeal setting, the tube was affixed to the columella using the same sutures.

When placing the tube in the oral setting in a supine position, the tube base was positioned anterior to the posterior of the 


\section{Fig. 1. Application of the Hemovac tube}

Application of the Hemovac tube in $(A)$ the pharyngeal setting and $(B)$ the oral setting. The eyelet holes of the tube must be placed within the nostril or the mouth for effective suction.
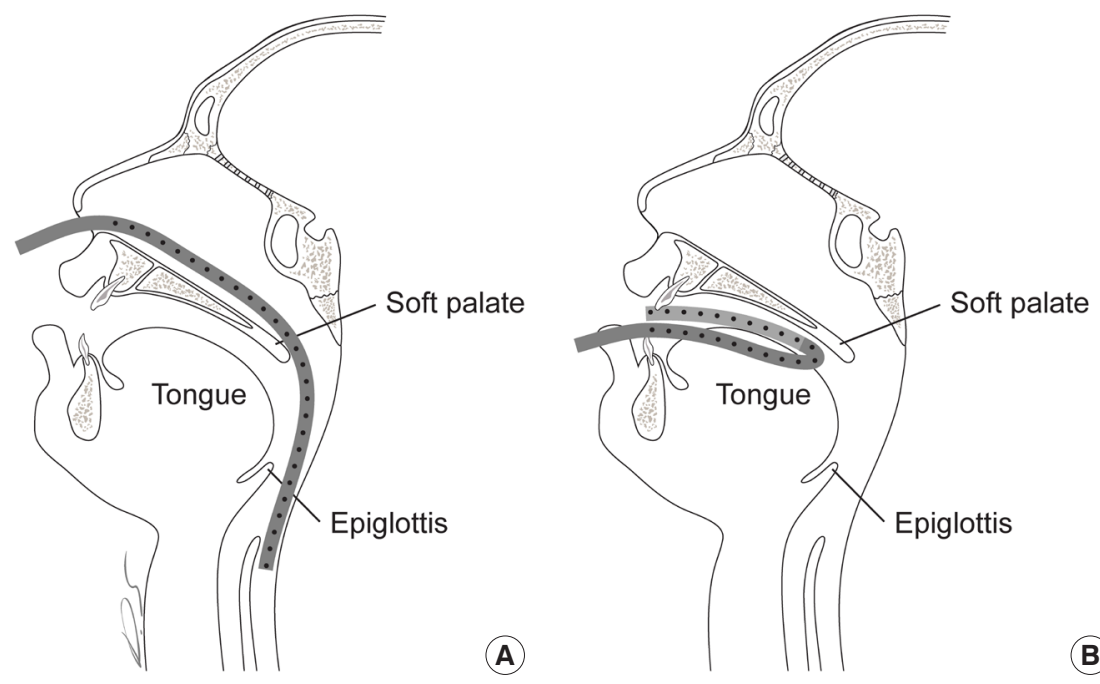

\section{Fig. 2. Tube in the oral setting}

The tube was positioned in a U-shape configuration in the oral setting. The base of the U-shaped tube should not be positioned too far back.

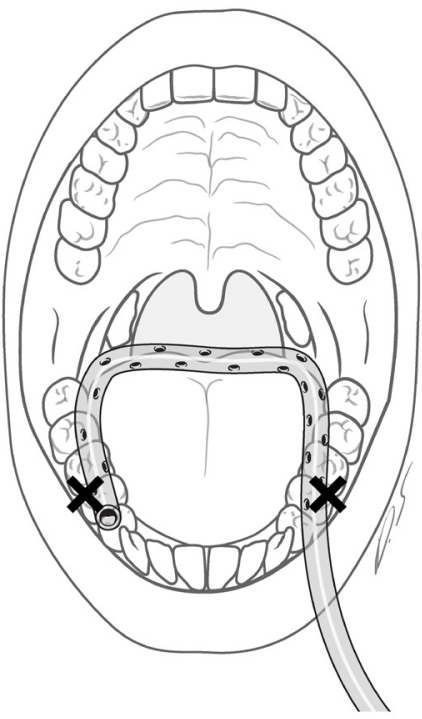

tongue base to prevent tube collapse upon tongue retrusion and swelling. If a tube is buried by a retruded tongue, the eyelet holes of the tube become exposed to the lateral side of the tongue, leading to pooling of saliva at the center of the oral cavity. This pooled saliva could leak via the sutures in the retromolar area and flow into the pharyngeal area.

When necessary, a bite block was placed orally. After the placement of a continuous suction tube, proper functioning was checked by irrigating the wound with saline. After surgery, the patient was transferred to the intensive care unit (ICU) with the tube fixed in place. Soon after the patient arrived in the ICU, a member of the medical personnel connected the tube to a Hemovac container via a connecting tube. The Hemovac container was then connected to the wall suction with an extension tube made of polyvinyl chloride (Fig. 3). Wall suction power was maintained at 30 to $40 \mathrm{~mm} \mathrm{Hg}$. Irrigation with distilled water or saline was performed to remove sediment and to prevent clogging. A member of the medical personnel performed this procedure by squirting 10 to $20 \mathrm{~mL}$ of distilled water into the mouth or nose on an hourly basis (Fig. 4).

The nurses and doctors performed irrigations during routine visits to check vital signs, administer medicines, and control the ventilators. Patients who recovered quickly performed self-irrigation. Owing to the simplicity of the procedure, irrigation did not add much to the workload of the medical staff.

The continuous suction system was applied in the oral setting in nine cases, and in both the oral and pharyngeal settings in nine cases. When the defect site also involved the hypopharynx and/or oropharynx, the pharyngeal setting was added (Fig. 5). If hemiglossectomy was performed, only the oral setting was used; however, if a total glossectomy was performed, the pharyngeal setting was used in addition to the oral setting.

\section{Statistical analysis}

Statistical analysis was performed using IBM SPSS version 23.0 (IBM Corp., Armonk, NY, USA). The mean and standard deviation of parameters were calculated. Continuous data were analyzed by the independent-samples 2 -tailed t-test. The Fisher exact or Pearson chi-square test was used for categorical data. Pvalues $<0.05$ were considered to indicate statistical significance. 


\section{Fig. 3. Configuration of the irrigation system}

The tube in the oral and/or pharyngeal setting was connected to an evacuator container, which was connected to wall suction via a pouring spout. PVC, polyvinyl chloride.

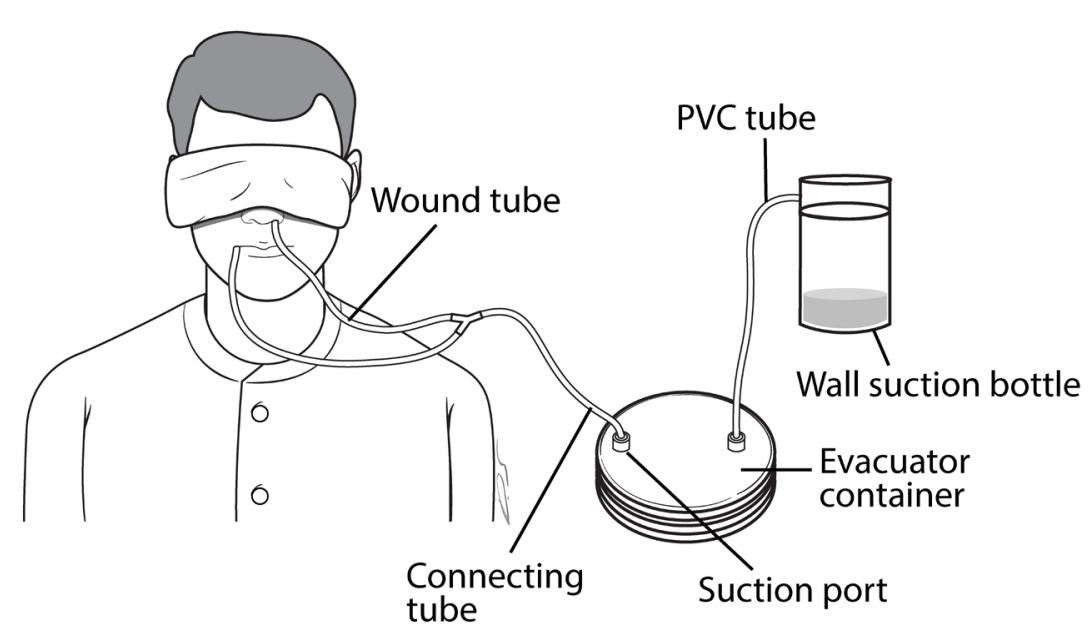

\section{Fig. 4. Wound care with distilled water irrigation}

Irrigation with distilled water in the intensive care unit. Hourly water irrigation was required to prevent sediment from clogging the tube.

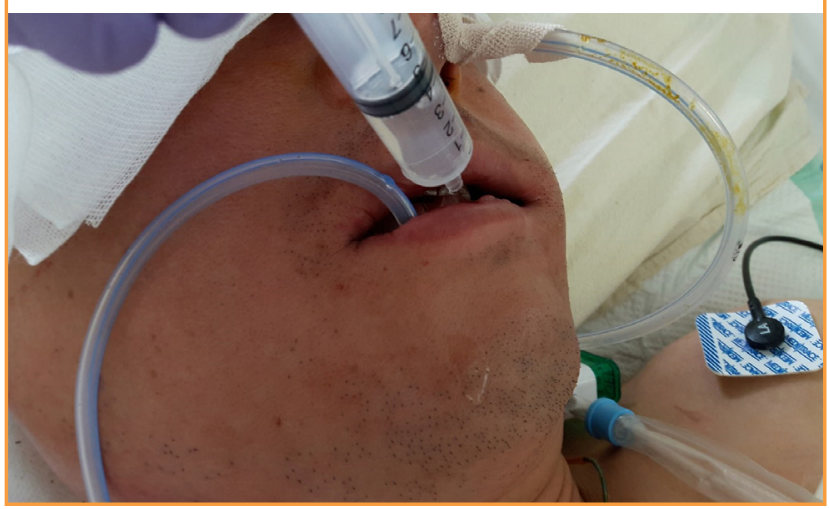

\section{RESULTS}

The clinical characteristics of the patients, including pathologic lesions, diagnosis, and type of continuous suction setting applied, are shown in Table 1 . There were 11 male and nine female patients who ranged in age from 28 to 81 years. The pathologic lesions were classified into the following location categories: oral cavity (oromandibular or buccal area), oropharynx, tongue, hypopharynx, and larynx. Some lesions were extended and combined. In patient \#2, tongue cancer extended into the upper hypopharynx. Hypopharyngeal cancers extended to the base of tongue and oropharynx in patients \#10 and \#15. Hypopharyngeal reconstruction for partial defects was performed in four patients, and oropharyngeal reconstruction was performed in six patients.

\section{Fig. 5. Tube placement in the oropharyngeal area \\ A radial forearm free flap was used to reconstruct the soft palate, tonsil, and lateral pharyngeal wall defect. Two tubes were placed in the posterior oropharyngeal wall. The tube on the patient's left was a L-tube (arrowhead), and the tube with holes on the patient's right was a continuous irrigation tube (arrow). The tube extended to the hypopharynx where the saliva pooled when the patient was lying in the supine position.}

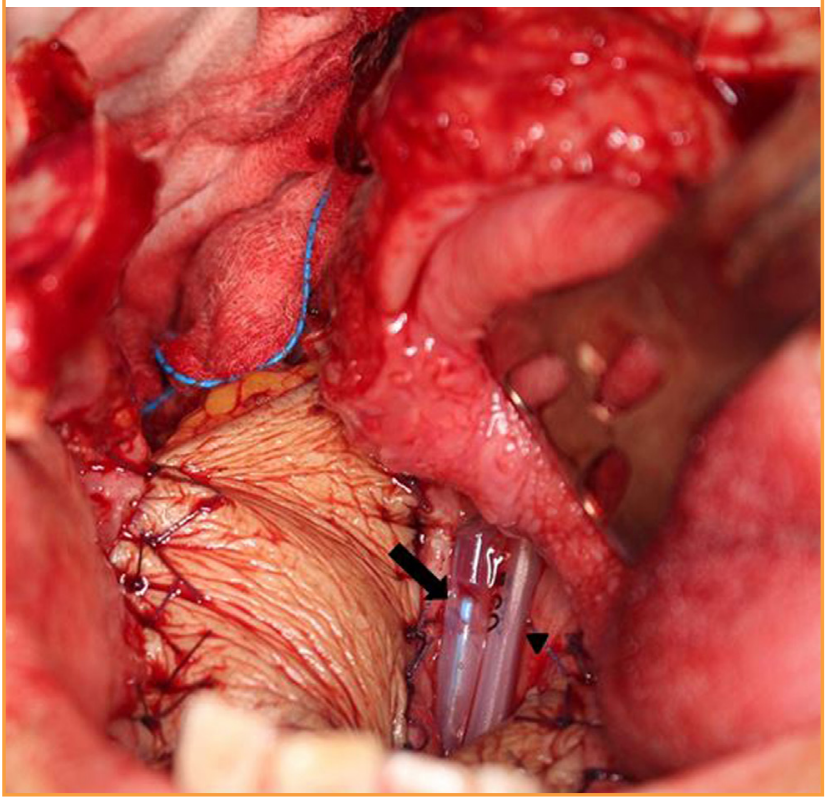

All reconstructions were performed with a single free flap, and the most commonly used flap was the anterolateral thigh flap (used in 17 cases). The other flaps used were the fibular osteocutaneous flap (in one case) and the rectus musculocutaneous flap (in two cases). This was similar to the non-suction group, where the anterolateral thigh flap was used in the majority of 


\section{Table 1. Patients' clinical characteristics (continuous suction group)}

\begin{tabular}{|c|c|c|c|c|c|c|c|c|c|c|c|}
\hline $\begin{array}{l}\text { Patient } \\
\text { No. }\end{array}$ & $\begin{array}{l}\text { Age } \\
\text { (yr) }\end{array}$ & Sex & $\begin{array}{l}\text { Diagnosis and } \\
\text { lesion }\end{array}$ & Pathology & $\begin{array}{l}\text { Flap } \\
\text { choice }\end{array}$ & $\begin{array}{c}\text { Neck } \\
\text { dissection }\end{array}$ & $\begin{array}{l}\text { Cancer } \\
\text { stage }\end{array}$ & $\begin{array}{l}\text { Continuous } \\
\text { suction } \\
\text { setting }\end{array}$ & $\begin{array}{l}\text { Continuous } \\
\text { suction } \\
\text { maintenance } \\
\text { (day) }\end{array}$ & $\begin{array}{l}\text { Previous } \\
\text { treatment/ } \\
\text { recurrence } \\
\text { interval }\end{array}$ & $\begin{array}{l}\text { Complication } \\
\text { (reason) }\end{array}$ \\
\hline 1 & 43 & M & $\begin{array}{l}\text { Tongue cancer } \\
\text { extending to the } \\
\text { hypopharynx }\end{array}$ & SCC & ALT & $\begin{array}{l}\text { Bilateral } \\
\text { SOND }\end{array}$ & IV & $\begin{array}{l}\text { Oral/ } \\
\text { pharyngeal }\end{array}$ & 9 & & $\begin{array}{l}\text { Leakage/partial N } \\
\text { (recipient tongue) }\end{array}$ \\
\hline 2 & 62 & $\mathrm{~F}$ & $\begin{array}{l}\text { Tongue cancer } \\
\text { extending to the } \\
\text { oropharynx and soft } \\
\text { palate }\end{array}$ & SCC & ALT & $\begin{array}{l}\text { Unilateral } \\
\text { SOND }\end{array}$ & IV & $\begin{array}{l}\text { Oral/ } \\
\text { pharyngeal }\end{array}$ & 9 & $\begin{array}{l}\text { Neoadjuvant } \\
\text { RTx/3 mo }\end{array}$ & \\
\hline 3 & 54 & M & $\begin{array}{l}\text { Tongue cancer involving } \\
\text { the mouth floor }\end{array}$ & SCC & $\begin{array}{l}\text { ALT } \\
\text { Pec Maj }\end{array}$ & $\begin{array}{l}\text { Unilateral } \\
\text { SOND }\end{array}$ & III & $\begin{array}{l}\text { Oral/ } \\
\text { pharyngeal }\end{array}$ & 8 & $\begin{array}{l}\text { Initial op /16 yr } \\
\text { Initial post-op } \\
\text { RTx/16 yr }\end{array}$ & $\begin{array}{l}\text { r Dehiscence/total N } \\
\text { (radionecrotic vessels) }\end{array}$ \\
\hline 4 & 52 & $\mathrm{~F}$ & $\begin{array}{l}\text { Oral cavity cancer of } \\
\text { the buccal area and } \\
\text { soft palate }\end{array}$ & SCC & ALT & $\begin{array}{l}\text { Unilateral } \\
\text { SOND }\end{array}$ & $\|$ & Oral & 6 & & \\
\hline 5 & 72 & $\mathrm{~F}$ & $\begin{array}{l}\text { Oral cavity cancer of } \\
\text { the buccal and } \\
\text { retromolar areas }\end{array}$ & SCC & ALT & None & $\|$ & $\begin{array}{l}\text { Oral/ } \\
\text { pharyngeal }\end{array}$ & 4 & $\begin{array}{l}\text { Initial op/8 yr } \\
\text { Initial post- } \\
\text { op RTx/6 yr }\end{array}$ & $\begin{array}{l}\text { Hematoma (release of } \\
\text { tie on branch of } \\
\text { external jugular vein) }\end{array}$ \\
\hline 6 & 59 & M & $\begin{array}{l}\text { Oral cavity cancer of } \\
\text { the buccal area }\end{array}$ & SCC & ALT & $\begin{array}{l}\text { Unilateral } \\
\text { SOND }\end{array}$ & IV & Oral & 10 & & \\
\hline 7 & 60 & $\mathrm{~F}$ & $\begin{array}{l}\text { Maxillary sinus cancer } \\
\text { of the maxilla and } \\
\text { orbit }\end{array}$ & Adeno Ca & ALT & None & IV & Oral & 7 & & \\
\hline 8 & 61 & $\mathrm{~F}$ & Tongue cancer & Adeno $\mathrm{Ca}$ & ALT & $\begin{array}{c}\text { Unilateral } \\
\text { SOND }\end{array}$ & $\|$ & Oral & 9 & & \\
\hline 9 & 63 & M & $\begin{array}{l}\text { Tongue cancer } \\
\text { extending to the } \\
\text { hypopharynx }\end{array}$ & SCC & $\begin{array}{l}\text { Rectus mc, } \\
\text { Pec Maj }\end{array}$ & $\begin{array}{c}\text { Bilateral } \\
\text { MRND }\end{array}$ & IV & $\begin{array}{l}\text { Oral/ } \\
\text { pharyngeal }\end{array}$ & 17 & $\begin{array}{l}\text { Pre-op RTx/30 } \\
\text { yr }\end{array}$ & $\begin{array}{l}\text { Dehiscence } \\
\text { (radionecrosis of neck } \\
\text { flap) }\end{array}$ \\
\hline 10 & 48 & $F$ & $\begin{array}{l}\text { Oral cavity cancer of } \\
\text { the buccal area } \\
\text { extending to the } \\
\text { maxilla and mandible }\end{array}$ & Pleom & Fibular oc & $\begin{array}{c}\text { Unilateral } \\
\text { MRND }\end{array}$ & IV & Oral & 13 & $\begin{array}{l}\text { Initial op/10 } \\
\text { mo, Initial } \\
\text { post-op } \\
\text { RTx/10 mo }\end{array}$ & \\
\hline 11 & 48 & M & $\begin{array}{l}\text { Tongue cancer involving } \\
\text { the mouth floor }\end{array}$ & SCC & ALT & $\begin{array}{l}\text { Unilateral } \\
\text { SOND }\end{array}$ & $\|$ & Oral & 7 & & \\
\hline 12 & 81 & $\mathrm{~F}$ & $\begin{array}{l}\text { Oral cavity cancer of } \\
\text { the mouth floor }\end{array}$ & SCC & ALT & $\begin{array}{l}\text { Unilateral } \\
\text { SOND }\end{array}$ & III & Oral & 1 & & \\
\hline 13 & 65 & $\mathrm{~F}$ & $\begin{array}{l}\text { Oral cavity cancer of } \\
\text { the mouth floor }\end{array}$ & Adeno $\mathrm{Ca}$ & ALT & None & III & Oral & 3 & Op/3 yr & \\
\hline 14 & 69 & M & $\begin{array}{l}\text { Hypopharyngeal cancer } \\
\text { extending to the base } \\
\text { of tongue and } \\
\text { oropharynx }\end{array}$ & SCC & ALT & $\begin{array}{l}\text { Unilateral } \\
\text { SOND }\end{array}$ & IV & $\begin{array}{l}\text { Oral/ } \\
\text { pharyngeal }\end{array}$ & 7 & & Fistula (POD 14) \\
\hline 15 & 52 & M & $\begin{array}{l}\text { Oropharyngeal cancer } \\
\text { of the soft palate and } \\
\text { tonsil }\end{array}$ & SCC & ALT & None & IV & $\begin{array}{l}\text { Oral/ } \\
\text { pharyngeal }\end{array}$ & 8 & & \\
\hline 16 & 79 & M & $\begin{array}{l}\text { Tongue cancer } \\
\text { extending to the larynx }\end{array}$ & SCC & Rectus mc & $\begin{array}{l}\text { Unilateral } \\
\text { MRND }\end{array}$ & IV & $\begin{array}{l}\text { Oral/ } \\
\text { pharyngeal }\end{array}$ & 7 & $\begin{array}{l}\text { Pre-op RTx/22 } \\
\text { yr }\end{array}$ & \\
\hline 17 & 28 & $\mathrm{~F}$ & $\begin{array}{l}\text { Oral cavity cancer of } \\
\text { the buccal area, } \\
\text { retromolar area, and } \\
\text { lower lip }\end{array}$ & SCC & ALT & $\begin{array}{l}\text { Unilateral } \\
\text { SOND }\end{array}$ & IV & Oral & 7 & $\begin{array}{l}\text { Initial op/3 yr, } \\
\text { Initial post- } \\
\text { op RTx/7 mo }\end{array}$ & \\
\hline 18 & 48 & M & $\begin{array}{l}\text { Tongue cancer involving } \\
\text { the mouth floor }\end{array}$ & SCC & ALT & $\begin{array}{c}\text { Unilateral } \\
\text { MRND }\end{array}$ & $\|$ & Oral & 5 & & \\
\hline 19 & 53 & M & $\begin{array}{l}\text { Hypopharyngeal cancer } \\
\text { extending to the base } \\
\text { of the tongue and } \\
\text { oropharynx }\end{array}$ & SCC & ALT & $\begin{array}{l}\text { Unilateral } \\
\text { SOND }\end{array}$ & IV & $\begin{array}{l}\text { Oral/ } \\
\text { pharyngeal }\end{array}$ & 6 & & $\begin{array}{l}\text { Partial N (venous } \\
\text { insufficiency/flap } \\
\text { congestion) }\end{array}$ \\
\hline 20 & 62 & M & $\begin{array}{l}\text { Hypopharyngeal cancer } \\
\text { extending to the base } \\
\text { of the tongue and } \\
\text { oropharynx }\end{array}$ & SCC & ALT & $\begin{array}{r}\text { Bilateral } \\
\text { MRND }\end{array}$ & IV & $\begin{array}{l}\text { Oral/ } \\
\text { pharyngeal }\end{array}$ & 7 & & \\
\hline
\end{tabular}


cases $(11 / 16)$. There was no statistically significant difference between the two groups in the types of flaps used. All the flaps used the superior thyroidal artery as the recipient artery. The pectoralis major musculocutaneous flap was used in two revision cases in the suction device group, and in three revision cases in the non-suction group. In the suction device group, one of the revision cases involved total necrosis of the initial free flap, and the other involved partial necrosis of the initial irradiated neck flap without any problem with the reconstructed free flap.

Eight patients underwent reconstruction due to cancer recurrence; for five of these eight patients, it was their second operation. The time between the first and second operations ranged from 10 months to 16 years. Five patients received radiotherapy before the operation. One patient received neoadjuvant radiotherapy, whereas four patients received postoperative radiotherapy. Robotic surgery was performed in four patients. No baseline clinical variables showed a statistically significant difference

\section{Table 2. Comparison of baseline patient characteristics}

\begin{tabular}{|c|c|c|c|}
\hline Variable & $\begin{array}{l}\text { Suction device } \\
\text { group } \\
(\mathrm{n}=\mathbf{2 0})\end{array}$ & $\begin{array}{l}\text { Non-suction } \\
\text { device group } \\
\quad(n=16)\end{array}$ & P-value \\
\hline Age (yr) & $57.95 \pm 12.45$ & $58.56 \pm 13.58$ & 0.890 \\
\hline Sex & & & 0.400 \\
\hline Male & $11 / 20(55)$ & $9 / 16(45)$ & \\
\hline Female & $11 / 20(68.8)$ & $5 / 16(31.3)$ & \\
\hline Pathology & & & 0.613 \\
\hline SCC & $16 / 20(80)$ & 15/16 (93.8) & \\
\hline Adeno ca. & $3 / 20(15)$ & $1 / 16(6.3)$ & \\
\hline Pleom & $1 / 20(5)$ & $0 / 16(0)$ & \\
\hline Type of flap & & & 0.204 \\
\hline ALT & $17 / 20(85)$ & $11 / 16(68.8)$ & \\
\hline Rectus mc & 2/20 (10) & $5 / 16(31.3)$ & \\
\hline Fibular oc & $1 / 20(5)$ & $0 / 16(0)$ & \\
\hline \multicolumn{4}{|l|}{ Neck dissection } \\
\hline Performed & $17 / 20(85)$ & $16 / 16(100)$ & \\
\hline Not performed & $3 / 20(15)$ & $0 / 16(0)$ & \\
\hline Cancer stage & & & 0.353 \\
\hline$\|$ & $5 / 20(25)$ & $1 / 16(6.3)$ & \\
\hline III & 2/20 (10) & 3/16 (18.8) & \\
\hline IV & $13 / 20(65)$ & $12 / 16(75)$ & \\
\hline Preoperative radiotherapy & & & 0.722 \\
\hline Performed & 5/20 (25) & 5/16 (31.3) & \\
\hline Not performed & $15 / 20(75)$ & $11 / 16(68.8)$ & \\
\hline \multicolumn{4}{|l|}{ Underlying disease } \\
\hline Hypertension & $8 / 20(40)$ & $8 / 16(50)$ & 0.549 \\
\hline Smoking history & $10 / 20(50)$ & $9 / 20(56.3)$ & 0.709 \\
\hline Diabetes mellitus & $3 / 20$ (15) & $4 / 16(25)$ & 0.675 \\
\hline $\begin{array}{l}\text { Previous head and neck } \\
\text { cancer }\end{array}$ & $8 / 20(40)$ & 2/16 (12.5) & 0.133 \\
\hline \multicolumn{4}{|c|}{$\begin{array}{l}\text { Values are presented as mean } \pm \text { SD or number/number (\%). } \\
\text { SCC, squamous cell carcinoma; Adeno ca, adenocarcinoma; Pleom, pleomorphic } \\
\text { carcinoma; ALT, anterolateral thigh flap; Rectus mc, rectus musculocutaneous } \\
\text { flap; Fibular oc, fibular osteocutaneous flap. }\end{array}$} \\
\hline
\end{tabular}

between the two groups (Table 2).

In the suction device group, the mean lengths of the hospital and ICU stays were $26.25 \pm 15.71$ and $3.35 \pm 0.99$ days, respectively. In the non-suction group, the mean lengths of the hospital and ICU stays were $43.75 \pm 22.97$ and $5.13 \pm 7.19$ days, respectively. The difference in hospitalization duration was statistically significant $(\mathrm{P}=0.010)$. This difference was in part due to the inclusion of two cases of donor skin graft loss in the nonsuction group, which required an additional skin graft procedure for wound coverage. In addition, one case of carotid rupture and one case of infection that eventually caused pneumonia substantially prolonged the hospitalization time in the non-suction group. The average number of days for the net drain output to fall below $10 \mathrm{~mL}$ was $6.50 \pm 2.80$ days in the suction group and $8.73 \pm 1.75$ days in the non-suction group $(\mathrm{P}=0.010)$. Effective elimination of pooled saliva, along with fewer wound problems, may have led to a lower amount of drainage in the suction group. Amylase concentrations in the wound drainage fluids, which were collected in sterile tubes, were measured. The mean amylase concentration in the drainage fluid was 1,315.50 IU and $1,685.40 \mathrm{IU}$ on day 3 after the operation in the suction and nonsuction groups, respectively (Table 3 ).

Complications were analyzed according to their causes and rates. Patient \# 1 received robotic hemiglossectomy through a face-lift incision. Reconstruction was difficult for this patient due to limited access to the surgical field. A partially necrotizing

Table 3. Comparison of length of hospitalization, ICU stay, HV drainage, and amylase levels

\begin{tabular}{|c|c|c|c|}
\hline Variable & $\begin{array}{l}\text { Suction device } \\
\text { group }(n=20)\end{array}$ & $\begin{array}{l}\text { Non-suction } \\
\text { device group } \\
\quad(n=16)\end{array}$ & P-value \\
\hline Length of stay (day) & & & 0.010 \\
\hline Mean $\pm S D$ & $26.25 \pm 15.71$ & $43.75 \pm 22.97$ & \\
\hline Range & 13-78 & 18-90 & \\
\hline Length of ICU stay (day) & & & 0.281 \\
\hline Mean \pm SD & $3.35 \pm 0.99$ & $5.13 \pm 7.19$ & \\
\hline Range & $2-5$ & $1-31$ & \\
\hline \multicolumn{4}{|l|}{$\begin{array}{l}\text { Maintenance of } \\
\text { continuous suction } \\
\text { (day) }\end{array}$} \\
\hline Mean \pm SD & $7.50 \pm 3.41$ & NA & \\
\hline Range & $1-17$ & NA & \\
\hline $\begin{array}{l}\text { HV drainage below } \\
10 \mathrm{~mL} \text { (day) }\end{array}$ & & & 0.011 \\
\hline Mean \pm SD & $6.50 \pm 2.80$ & $8.73 \pm 1.75$ & \\
\hline Range & 3-13 & 6-12 & \\
\hline $\begin{array}{l}\text { Amylase level on day } \\
3(\mathrm{U} / \mathrm{L})\end{array}$ & & & 0.734 \\
\hline Mean \pm SD & $1,315.50 \pm 2,177.09$ & $1,685.40 \pm 2,605.75$ & \\
\hline Range & $15-7,677$ & $40-7,201$ & \\
\hline
\end{tabular}


lesion led to dehiscence of the wound, and saliva leaked through this site. The leakage site was repaired 3 days after surgery, and the wound healed well thereafter. A complication occurred in patient \#3 due to microsurgical failure. The recipient vessels for this patient were not optimal due to previous radical neck dissection and radiotherapy. Although a good pulsating artery was used, arterial flow was not detected on day 2 after the operation. This resulted in necrosis of the flap, and a pectoralis major flap was performed subsequently. Hematoma in patient $\# 5$ resulted from the release of a tie at the branch of an external jugular vein. Lastly, a complication in patient \#9 resulted from wound dehiscence at the previously irradiated neck flap. Neither salivary leakage nor flap necrosis was noted, and the dehiscence healed well after revision. Fistula formation in patient \#14 occurred 14 days after surgery. We noted that partial necrosis of the flap led to saliva leakage, which eventually resulted in fistula formation.

Table 4 shows the rates of fistula/leakage, infection, hemato$\mathrm{ma} /$ bleeding, wound dehiscence, and flap necrosis in the two groups. The only complication that showed a statistically significant difference between the groups was infection. As listed in Supplemental Table 1, the following criteria were used to determine surgical infection: a wound with clinical suspicion of infection with 1 or more positive cultures and $3+$ neutrophils that were not associated with contaminant flora. The evaluating clinician was also required to agree with the criteria. Patient \#15 (non-suction group) had an erythematous lesion with foul discharge that cultured positive for MRSA. This delay in wound healing eventually required salvage surgery to cover the infection site. Patient \#16 also developed dehiscence due to MRSA infection. Even after multiple revision attempts, the wound did not heal. In addition, poor oral hygiene delayed wound healing, and the patient eventually underwent salvage surgery to repair the wound. Patient \#14 presented with delayed onset of fever and clinical suspicion of infection, but a culture was negative. Therefore, this patient did not meet the criteria for infection.

\section{Table 4. Complications after reconstructive surgery}

\begin{tabular}{|lccc|}
\hline \multirow{2}{*}{ Events } & \multicolumn{2}{c|}{ Incidence } & \\
\cline { 2 - 3 } & $\begin{array}{c}\text { Suction } \\
\text { device group } \\
(\mathbf{n}=\mathbf{2 0})\end{array}$ & $\begin{array}{c}\text { Non-suction } \\
\text { device group } \\
(\mathbf{n}=\mathbf{1 6})\end{array}$ & P-value \\
\hline Fistula/leakage & $2(10)$ & $1(6.3)$ & 1.0 \\
Infection & 0 & $4(25)$ & 0.031 \\
Hematoma/bleeding & $1(5)$ & $2(12.5)$ & 0.574 \\
Wound dehiscence & $2(10)$ & $2(12.5)$ & 1.0 \\
Flap necrosis (partial/total) & $2(10)$ & $2(12.5)$ & 1.0 \\
\hline Values are presented as number (\%). & & \\
\hline
\end{tabular}

\section{DISCUSSION}

Improved diagnostics, surgical methods, advancements in microsurgical techniques, and knowledge of flap anatomy have allowed more patients to receive head and neck reconstructive surgery, while also improving the overall free flap survival rate [1-3]. Nonetheless, these advances have not yet reduced the rate of fistula formation, and fistula treatment remains conservative $[10,12]$. Recently, in an attempt to preserve speech and swallowing functions, an organ preservation protocol that includes concurrent chemoradiotherapy has been performed preoperatively and postoperatively. This practice has in fact increased the number of recurrences, and raised concerns among reconstructive surgeons due to the increased rate of flap failure and fistula formation $[2,20]$. Additionally, the introduction of robotic and endoscopic surgery has further complicated reconstruction due to poor visibility when insetting the flap. Robotic neck dissection uses a rhytidectomy incision without a mandible sling, which is a step forward in the aesthetic aspect; however, it compromises visibility when insetting the flap during reconstruction. Although no wide-scale analysis has been conducted of the effects of chemoradiotherapy and robotic dissections on the flap failure rate, fibrosis caused by irradiation and recurrent operations may contribute to friable vessel patency.

Previous studies reported that the institution type, flap choice, and surgical method did not affect the incidence of fistula formation or the incidence of secondary complications arising after fistula formation. Problems such as delayed wound healing, vessel patency issues, longer hospital stay, and carotid artery rupture have been reported to occur after fistula formation $[4,6,8]$. Preventive measures include a novel suture technique and double folding of the flap $[2,3,12]$. In addition to preventive surgical techniques, primary care measures, including the insertion of a Montgomery salivary stent and L-tube, have been reported $[7,8,14,21]$.

We observed that saliva pools on surgical wounds after head and neck reconstructive surgery. We speculated that this occurs because patients are supine for some time after surgery, and the supine position provides reservoirs for saliva to collect in the mouth floor, retromolar area, and hypopharynx area. Past studies and clinical observations have shown that saliva leaks even when surgical sutures are flawless. It has been suggested that fistula formation can be predicted by measuring amylase levels in the neck drainage fluid [22]. Although amylase levels between the two groups were compared, their difference was not statistically significant. This may have been because the elevation of amylase levels is affected by not only fistula formation, but also by other complications, such as flap necrosis and wound dehiscence. 
Saliva pooling occurs due to collapse of the esophagus after reconstruction and/or oropharyngeal edema. After reconstruction, a tongue with edema may retrude and obstruct the oropharynx. To prevent pooled saliva from causing wound problems, successful removal of saliva during the early recovery phase after an operation is essential.

Fistula formation is not confined to the hypopharynx and larynx $[4,5,12,23]$. We observed that fistula formation could occur wherever there was stagnant saliva. Pooled saliva can leak through wound margins in the oral area and/or hypopharynx. Even after tongue reconstruction, the retromolar area can serve as a salivary reservoir, which may delay wound healing and lead to fistula formation. Therefore, the oral cavity and hypopharynx are the two anatomical locations that must be considered to effectively remove salivary reservoirs, which is why the suction system was applied to these areas in this study.

We used a continuous suction tube with multiple eyelets, as tubes with 1 or 2 eyelets are easily clogged, leading to ineffective suction. The eyelets of the Hemovac tube were placed within the nasal or oral cavity since exposure of eyelets would lower the negative pressure gradient, thereby making the system ineffective.

Although the oral and pharyngeal tubes could have been connected directly to the wall suction bottle using an extension tube, we connected them to a Hemovac evacuator container between the tube and wall suction bottle, since the container allowed the system to run at a minimal suction power while maintaining negative pressure throughout the tube. Too much suction power must be avoided, since it could cause the flap to become too cold. By irrigation with distilled water or saline, the proper functioning of the suction system could be evaluated. Tubes placed in the pharyngeal setting tend to clog easily, as the nasal mucosa produces a large amount of secretions. Routine irrigation of the tube prevented this clogging problem.

Once a wound problem arises, necrotic tissues and pooled saliva may exacerbate wound problems by delaying healing. Such a delay may cause the wound to deteriorate further through a nosocomial infection. Continuous suction allowed frequent irrigation to maintain good oral hygiene. The comparison between the two groups in this study showed that the continuous suction system not only eliminated pooled saliva but also promoted wound healing by allowing good oral hygiene to be maintained. Attention to oral hygiene is often neglected due to difficulties in implementation; however, this system enables the simple maintenance of oral hygiene to minimize the risk of gingivitis, mucositis, and surgical site infection, thereby decreasing the risk associated with fistula formation.

During a mean follow-up period of 9.2 months in the suction group, fistula occurred in two cases. In the rest of the patients, the wounds healed well, although we performed secondary surgery due to vessel failure and hematoma. In the two patients with fistula, the fistula occurred due to partial necrosis of the flap. After revision, a continuous suction system was applied, and the wound healed without any complications. We noticed reduced saliva pooling and an improvement in wound healing, even in patients who underwent secondary surgery. This is in contrast to one patient in the non-suction group who did not heal after multiple rounds of salvage surgery. After subsequent attempts to repair a failed flap, surgical site infection occurred and eventually resulted in rupture of the carotid artery (patient \#1 in Supplemental Table 2). Infection and fistula formation after failed primary surgery predispose the vessel to salivary leakage. Less leakage of saliva may be an essential consideration since saliva may cause fatal complications, such as carotid blowout syndrome, in some cases $[1,3,9,15,24]$.

Although the application of an easy-to-place suction system does not itself prevent fistula formation, our study showed that it did promote good hygiene and lowered the surgical infection rate. Future prospective studies with a larger number of cases would further elucidate the effectiveness of applying this system.

Our study was limited by the small number of patients evaluated, as well as the short follow-up period. In addition, fistula formation confined to pharyngectomies and laryngectomies should be analyzed. Although placing a tube in the mouth and nose may cause some discomfort to the patient, our study showed that applying the system for a short period after surgery in patients with previous wound problems may be beneficial, and that it prevented delays in wound healing. The application of a continuous suction system with timely irrigation was effective in removing saliva and maintaining oral hygiene.

\section{NOTES}

\section{Conflict of interest}

No potential conflict of interest relevant to this article was reported.

\section{Ethical approval}

The study was approved by the Institutional Review Board of Severance Hospital (IRB No. 4-2018-0402) and performed in accordance with the principles of the Declaration of Helsinki. Written informed consents were obtained.

\section{Patient consent}

The patients provided written informed consent for the publication and the use of their images. 


\section{ORCID}

Hsien Pin Chang https://orcid.org/0000-0002-2861-6371

Jong Won Hong https://orcid.org/0000-0002-7762-0940

\section{REFERENCES}

1. Haughey BH, Wilson E, Kluwe L, et al. Free flap reconstruction of the head and neck: analysis of 241 cases. Otolaryngol Head Neck Surg 2001;125:10-7.

2. Sayles M, Grant DG. Preventing pharyngo-cutaneous fistula in total laryngectomy: a systematic review and meta-analysis. Laryngoscope 2014;124:1150-63.

3. Pohlenz P, Klatt J, Schon G, et al. Microvascular free flaps in head and neck surgery: complications and outcome of 1000 flaps. Int J Oral Maxillofac Surg 2012;41:739-43.

4. Makitie AA, Irish J, Gullane PJ. Pharyngocutaneous fistula. Curr Opin Otolaryngol Head Neck Surg 2003;11:78-84.

5. Larsen LR, Schuller DE. Wound amylase levels as an early indicator of orocutaneous fistulae. Laryngoscope 1984;94: 1302-6.

6. Piazza C, Taglietti V, Nicolai P. Reconstructive options after total laryngectomy with subtotal or circumferential hypopharyngectomy and cervical esophagectomy. Curr Opin Otolaryngol Head Neck Surg 2012;20:77-88.

7. Redaelli de Zinis LO, Ferrari L, Tomenzoli D, et al. Postlaryngectomy pharyngocutaneous fistula: incidence, predisposing factors, and therapy. Head Neck 1999;21:131-8.

8. Horgan EC, Dedo HH. Prevention of major and minor fistulae after laryngectomy. Laryngoscope 1979;89(2 Pt 1): 250-60.

9. Lee T, Chung C, Chang Y, et al. Comparison of clinical and functional outcomes using pectoralis major and cutaneous free flaps for hypopharyngeal squamous cell carcinoma. Arch Plast Surg 2015;42:608-13.

10. Bomeli SR, Desai SC, Johnson JT, et al. Management of salivary flow in head and neck cancer patients: a systematic review. Oral Oncol 2008;44:1000-8.

11. Sweeny L, Rosenthal EL, Light T, et al. Effect of overlapping operations on outcomes in microvascular reconstructions of the head and neck. Otolaryngol Head Neck Surg 2017;156: 627-35.
12. Al Deek NF, Wei FC, Tsao CK. Fistulae after successful free tissue transfer to head and neck: its prevention and treatment. Clin Plast Surg 2016;43:739-45.

13. Bozikov K, Arnez ZM. Factors predicting free flap complications in head and neck reconstruction. J Plast Reconstr Aesthet Surg 2006;59:737-42.

14. Galli J, De Corso E, Volante M, et al. Postlaryngectomy pharyngocutaneous fistula: incidence, predisposing factors, and therapy. Otolaryngol Head Neck Surg 2005;133:689-94.

15. Eckardt A, Fokas K. Microsurgical reconstruction in the head and neck region: an 18-year experience with 500 consecutive cases. J Craniomaxillofac Surg 2003;31:197-201.

16. Bianchi B, Copelli C, Ferrari S, et al. Free flaps: outcomes and complications in head and neck reconstructions. J Craniomaxillofac Surg 2009;37:438-42.

17. Durand ML, Yarlagadda BB, Rich DL, et al. The time course and microbiology of surgical site infections after head and neck free flap surgery. Laryngoscope 2015;125:1084-9.

18. Chaukar DA, Deshmukh AD, Majeed T, et al. Factors affecting wound complications in head and neck surgery: a prospective study. Indian J Med Paediatr Oncol 2013;34:24751.

19. Upile T, Triaridis S, Kirkland P, et al. The management of carotid artery rupture. Eur Arch Otorhinolaryngol 2005; 262:555-60.

20. White HN, Golden B, Sweeny L, et al. Assessment and incidence of salivary leak following laryngectomy. Laryngoscope 2012;122:1796-9.

21. Bondi S, Giordano L, Limardo P, et al. Role of Montgomery salivary stent placement during pharyngolaryngectomy, to prevent pharyngocutaneous fistula in high-risk patients. J Laryngol Otol 2013;127:54-7.

22. Morton RP, Mehanna H, Hall FT, et al. Prediction of pharyngocutaneous fistulas after laryngectomy. Otolaryngol Head Neck Surg 2007;136(4 Suppl):S46-9.

23. Kolokythas A. Long-term surgical complications in the oral cancer patient: a comprehensive review. Part II. J Oral Maxillofac Res 2010;1:e2.

24. Pohlenz P, Blessmann M, Heiland M, et al. Postoperative complications in 202 cases of microvascular head and neck reconstruction. J Craniomaxillofac Surg 2007;35:311-5.

\section{Supplementary Material}

Supplemental Table 1. Clinical criteria for surgical site infection

Supplemental Table 2. Patients' clinical characteristics (non-continuous suction group) 


\begin{tabular}{|lrrr|r|}
\hline Clinical criterion & \multicolumn{1}{c}{ Culture result } & Direct examination result & Clinical response to culture result \\
\hline $\begin{array}{l}\text { Erythematous or purulent lesion (with foul } \\
\text { discharge) with clinical suspicion of } \\
\text { infection }\end{array}$ & $\begin{array}{c}\geq 1 \text { Positive culture from the site of } \\
\text { clinical suspicion }\end{array}$ & $\geq 3+$ neutrophils ( $<1$ per $\times 100$ field) & $\begin{array}{c}\text { Clinician agrees that isolate is the true cause } \\
\text { of the infection }\end{array}$ \\
\hline Reported as infection with clinical significance only when the above 4 criteria were met. & \\
\hline
\end{tabular}




\section{Supplemental Table 2. Patients' clinical characteristics (non-continuous suction group)}

\begin{tabular}{|c|c|c|c|c|c|c|c|c|c|}
\hline $\begin{array}{l}\text { Patient } \\
\text { No. }\end{array}$ & Age (yr) & Sex & $\begin{array}{l}\text { Diagnosis and } \\
\text { lesion }\end{array}$ & Pathology & $\begin{array}{l}\text { Flap } \\
\text { choice }\end{array}$ & $\begin{array}{c}\text { Neck } \\
\text { dissection }\end{array}$ & $\begin{array}{l}\text { Cancer } \\
\text { stage }\end{array}$ & $\begin{array}{l}\text { Previous } \\
\text { treatment/ } \\
\text { recurrence } \\
\text { interval }\end{array}$ & $\begin{array}{l}\text { Complication } \\
\text { (reason) }\end{array}$ \\
\hline 1 & 74 & M & $\begin{array}{l}\text { Oral cavity cancer of the } \\
\text { mouth floor }\end{array}$ & SCC & $\begin{array}{l}\text { Rectus mc } \\
\text { Pec Maj }\end{array}$ & $\begin{array}{l}\text { Lt. SOND } \\
\text { Rt. MRND }\end{array}$ & IV & Initial op/1 yr & $\begin{array}{l}\text { Total N (compressed vessel)/ } \\
\text { infection fistula/ECA tearing }\end{array}$ \\
\hline 2 & 64 & $M$ & Tongue cancer & SCC & ALT & Unilateral SOND & III & & \\
\hline 3 & 61 & M & $\begin{array}{l}\text { Oral cavity cancer of the } \\
\text { mouth floor }\end{array}$ & SCC & ALT & Bilateral SOND & IV & & \\
\hline 4 & 57 & M & $\begin{array}{l}\text { Ora cavity cancer of the } \\
\text { mouth floor }\end{array}$ & SCC & Rectus mc & $\begin{array}{l}\text { Rt. SOND } \\
\text { Lt. MRND }\end{array}$ & IV & & \\
\hline 5 & 28 & $\mathrm{~F}$ & $\begin{array}{l}\text { Tongue cancer involving } \\
\text { the mouth floor }\end{array}$ & SCC & Rectus mc & Bilateral SOND & $\|$ & & $\begin{array}{l}\text { Infection (delayed wound } \\
\text { healing) }\end{array}$ \\
\hline 6 & 67 & M & Hypopharyngeal cancer & SCC & ALT & Bilateral SOND & IV & Pre-op CCRTx/7 mo & \\
\hline 7 & 50 & $\mathrm{~F}$ & $\begin{array}{l}\text { Tongue cancer involving } \\
\text { the mouth floor }\end{array}$ & SCC & ALT & Bilateral SOND & IV & $\begin{array}{l}\text { Initial op/16 yr } \\
\text { Pre-op RTx/4 mo }\end{array}$ & \\
\hline 8 & 58 & M & $\begin{array}{l}\text { Tongue cancer extending } \\
\text { to the hypopharynx }\end{array}$ & SCC & ALT & $\begin{array}{l}\text { Rt. MRND } \\
\text { Lt. SOND }\end{array}$ & IV & Pre-op CTx/ & \\
\hline 9 & 74 & $\mathrm{~F}$ & $\begin{array}{l}\text { Tongue cancer extending } \\
\text { to the hypopharynx }\end{array}$ & SCC & Rectus mc & $\begin{array}{l}\text { Rt. MRND } \\
\text { Lt. SOND }\end{array}$ & IV & & \\
\hline 10 & 53 & $\mathrm{~F}$ & $\begin{array}{l}\text { Tongue cancer extending } \\
\text { to the hypopharynx }\end{array}$ & Adeno $\mathrm{Ca}$ & ALT & $\begin{array}{l}\text { Rt. MRND } \\
\text { Lt. SOND }\end{array}$ & IV & & \\
\hline 11 & 73 & M & $\begin{array}{l}\text { Tongue cancer involving } \\
\text { the mouth floor }\end{array}$ & SCC & ALT & Bilateral SOND & IV & Pre-op RTx/2 yr & $\begin{array}{l}\text { Anastomosis site rupture } \\
\text { (hematoma) }\end{array}$ \\
\hline 12 & 67 & M & $\begin{array}{l}\text { Tongue cancer involving } \\
\text { the mouth floor }\end{array}$ & SCC & ALT & Bilateral SOND & III & & \\
\hline 13 & 31 & $\mathrm{~F}$ & $\begin{array}{l}\text { Tongue cancer involving } \\
\text { the mouth floor }\end{array}$ & SCC & Rectus mc & Unilateral MRND & IV & Pre-op CCRTx/18 mo & \\
\hline 14 & 63 & M & $\begin{array}{l}\text { Oropharyngeal cancer } \\
\text { involving the tonsil and } \\
\text { buccal mucosa }\end{array}$ & SCC & ALT & Unilateral MRND & IV & & $\begin{array}{l}\text { Delayed onset of fever at POD } \\
16 \text { Clinical suspicion of } \\
\text { infection (culture: no growth) }\end{array}$ \\
\hline 15 & 63 & M & $\begin{array}{l}\text { Laryngeal and } \\
\text { hypopharyngeal cancer }\end{array}$ & SCC & $\begin{array}{l}\text { ALT } \\
\text { Pec Maj }\end{array}$ & $\begin{array}{l}\text { Rt. SOND } \\
\text { Lt. MRN }\end{array}$ & IV & Pre-op RTx/8 mo & $\begin{array}{l}\text { Flap N/dehiscence infection } \\
\text { (MRSA) }\end{array}$ \\
\hline 16 & 53 & M & $\begin{array}{l}\text { Tongue cancer involving } \\
\text { the mouth floor }\end{array}$ & SCC & $\begin{array}{l}\text { ALT } \\
\text { Pec Maj }\end{array}$ & $\begin{array}{l}\text { Rt. MRND Lt. } \\
\text { SOND }\end{array}$ & III & & Infection (MRSA)/dehiscence \\
\hline
\end{tabular}

M, male; SCC, squamous cell carcinoma; Pec Maj, pectoralis major myocutaneous flap; Lt., left; SOND, supraomohyoid neck dissection; Rt., right; MRND, modified radical neck dissection; op, operation; N, necrosis; ECA, external carotid artery; ALT, anterolateral thigh flap; Rectus mc, rectus musculocutaneous flap; F, female; CCRTx, concurrent chemoradiotherapy; RTx, radiotherapy; Adeno Ca, adenocarcinoma; POD, postoperative day; Pec Maj, pectoralis major myocutaneous flap; MRSA, methicillin-resistant Staphylococcus aureus. 